\title{
Microzooplankton herbivory and phytoplankton growth in the northwestern Sargasso Sea
}

\author{
Evelyn J. Lessard*, Michael C. Murrell**
}

School of Oceanography, University of Washington, Box 357940, Seattle, Washington 98195, USA

\begin{abstract}
Microzooplankton grazing and phytoplankton growth rates were measured with the dilution technique during spring, summer and fall in the oligotrophic Sargasso Sea near Bermuda. Phytoplankton growth rates estimated from changes in chlorophyll a ranged from 0.2 to $0.8 \mathrm{~d}^{-1}$ and grazing rates from undetectable to $0.8 \mathrm{~d}^{-1}$. Grazing rates approximately balanced or exceeded growth rates, except on 1 date when no grazing was detected. The results support the view that phytoplankton in the subtropical oligotrophic gyres are growing at high, but sub-maximal, rates and are grazed to low stable biomass levels. Chlorophyll grazing rates in the surface mixed layer could be related to ambient chlorophyll levels by a Michaelis-Menten model with a grazing threshold. The close correspondence between the apparent feeding threshold level and the observed lower limit of chlorophyll concentration in the surface water of the Sargasso Sea suggests that the lower biomass limit may be related to threshold feeding behavior of the grazer community.
\end{abstract}

KEY WORDS: Microzooplankton grazing - Sargasso Sea $\cdot$ Dilution experiments · Oligotrophic oceans

\section{INTRODUCTION}

The nutrient-depleted central oligotrophic oceans were once thought to be unproductive regions (Ryther 1969) with slow-growing phytoplankton (Eppley 1980), but more extensive sampling using modern methods has shown that productivity and phytoplankton growth rates are, in fact, relatively high (e.g. Laws et al. 1987, Taguchi et al. 1988, Lohrenz et al. 1992, Malone et al. 1993). In the northwestern Sargasso Sea, deep convective mixing in late winter injects nutrients into the surface layer, leading to an annual late-winter bloom after the water column restratifies (Menzel \& Ryther 1960, Michaels et al. 1994). Unlike typical temperate spring blooms, the bloom is dominated by small prokaryotic and eukaryotic algae, rather than diatoms (although diatoms also show a spring increase; Michaels et al. 1994). Picoplankton $(<2 \mu \mathrm{m})$ account for up to $80 \%$ of the biomass and primary production throughout most of the year (Li et al. 1983, Platt et al. 1983, Malone et al.

\footnotetext{
•E-mail: elessard@u.washington.edu

-Present address: Department of Ocean Sciences, University of California, Santa Cruz, California 95064, USA
}

1993). The autotrophic picoplankton are comprised primarily of the prokaryotes Synechococcus and Prochlorococcus, and small eukaryotes (Waterbury et al. 1986, Chisholm et al. 1988, Li et al. 1992). Due to the small size and potentially fast growth rates of these autotrophs, their most likely consumers are phagotrophic protists. While a few studies have documented the abundance and biomass of protists in the oligotrophic gyres (e.g. Beers et al. 1982, Sorokin et al. 1985, Caron et al. 1995, Lessard \& Murrell 1996), the quantitative role of protists as grazers has not been well studied.

Although there is a seasonal phytoplankton bloom in the Sargasso Sea, the accumulation of biomass is very small $\left(<0.2 \mu \mathrm{g}\right.$ chl $\mathrm{l}^{-1}$ in the surface water, $<0.5 \mu \mathrm{g} \mathrm{chl} \mathrm{^{-1 }}$ in the deep chlorophyll maximum, Michaels et al. 1994). Throughout most of the year, phytoplankton standing stock in the surface waters is

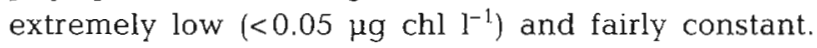
Satellite measurements have shown that low constant phytoplankton biomass is characteristic of the oligotrophic gyres over large distances 11000 s of km, Feldman et al. 1989) and for much of the year (monthly medians of chlorophyll only vary by a factor of 2 to 4 , 
Banse \& English 1994). Physical losses from vertical mixing and advection in the open ocean are too small to balance growth; therefore grazing has been invoked as the major loss of phytoplankton biomass (Banse 1992). Empirical evidence is accumulating that grazing largely balances phytoplankton growth in other areas of the ocean where phytoplankton biomass also remains relatively constant (e.g. the Subarctic Pacific, Strom \& Welschmeyer 1991, Landry et al. 1993; the Equatorial Pacific, Landry et al. 1995a, 1997, Verity et al, 1996). Lacking for the oligotrophic gyres are direct measurements of the grazing activities of protists which would allow a quantitative assessment of their role in regulating phytoplankton stocks. In this study, we report experimental estimates of microzooplankton community grazing in the oligotrophic Sargasso Sea.

\section{METHODS}

The dilution method (Landry \& Hassett 1982) was used to measure grazing and growth of phytoplankton on 2 cruises in the vicinity of the JGOFS long-term time-series station southeast of Bermuda $\left(31^{\circ} 50^{\prime} \mathrm{N}\right.$, $\left.64^{\circ} 10^{\prime} \mathrm{W}\right)$ during March-April 1990 and August 1991 and 1 cruise north of Bermuda $\left(36^{\circ} \mathrm{N}, 63^{\circ}-67^{\circ} \mathrm{W}\right)$ in October 1990. The March-April 1990 cruise was part of the ZOOSWAT program (Roman et al. 1995, Lessard \& Murrell 1996). On all 3 cruises, experiments were conducted with water from the surface mixed layer; on the spring cruise, 4 experiments also were performed with water from the deep chlorophyll maximum (DCM). Dates and conditions for the experiments are listed in Table 1.

Table 1. Date, location, depth $(Z)$ of water sample, incubation light level (\% incident light) and temperature $(T)$ for each set of dilution experiments

\begin{tabular}{|llrrr|}
\hline Date & Location & $Z(\mathrm{~m})$ & $\% I_{0}$ & $T\left({ }^{\circ} \mathrm{C}\right)$ \\
\hline 25 Mar 90 & $31^{\circ} 44^{\prime} \mathrm{N}, 64^{\circ} 14^{\prime} \mathrm{W}$ & 10 & 63 & 1974 \\
27 Mar 90 & $31^{\circ} 44^{\prime} \mathrm{N}, 64^{\circ} 14^{\prime} \mathrm{W}$ & 62 & 4 & 19.24 \\
$29 \operatorname{Mar} 90$ & $31^{\circ} 43^{\prime} \mathrm{N}, 64^{\circ} 14^{\prime} \mathrm{W}$ & 63 & 4 & 1.9 .19 \\
31 Mar 90 & $31^{\circ} 44^{\prime} \mathrm{N}, 64^{\circ} 14^{\prime} \mathrm{W}$ & 1 & 63 & 19.36 \\
2 Apr 90 & $31^{\circ} 57^{\prime} \mathrm{N}, 64^{\circ} 19^{\prime} \mathrm{W}$ & 1 & 63 & 20.60 \\
6 Apr 90 & $31^{\circ} 44^{\prime} \mathrm{N}, 64^{\circ} 14^{\prime} \mathrm{W}$ & 50 & 10 & 19.20 \\
8 Apr 90 & $31^{\circ} 44^{\prime} \mathrm{N}, 64^{\circ} 14^{\prime} \mathrm{W}$ & 42 & 10 & 20.46 \\
13 Oct 90 & $35^{\circ} 40^{\prime} \mathrm{N}, 63^{\circ} 00^{\prime} \mathrm{W}$ & 20 & 63 & 25.40 \\
18 Oct 90 & $35^{\circ} 40^{\prime} \mathrm{N}, 63^{\circ} 00^{\prime} \mathrm{W}$ & 10 & 63 & 24.90 \\
20 Oct 90 & $36^{\circ} 00^{\prime} \mathrm{N}, 67^{\circ} 00^{\prime} \mathrm{W}$ & 10 & 63 & 25.00 \\
22 Oct 90 & $36^{\circ} 00^{\prime} \mathrm{N}, 67^{\circ} 00^{\prime} \mathrm{W}$ & 10 & 63 & 25.00 \\
10 Aug 91 & $31^{\circ} 42^{\prime} \mathrm{N}, 64^{\circ} 10^{\prime} \mathrm{W}$ & 15 & 63 & 28.60 \\
14 Aug 91 & $31^{\circ} 42^{\prime} \mathrm{N}, 64^{\circ} 10^{\prime} \mathrm{W}$ & 15 & 63 & 29.12 \\
16 Aug 91 & $31^{\circ} 42^{\prime} \mathrm{N}, 64^{\circ} 10^{\prime} \mathrm{W}$ & 15 & 63 & 28.88 \\
19 Aug 91 & $31^{\circ} 42^{\prime} \mathrm{N}, 64^{\circ} 10^{\prime} \mathrm{W}$ & 15 & 63 & 26.65 \\
\hline
\end{tabular}

Experimental design. Water for dilution experiments was obtained with acid-cleaned, 30 I Niskin bottles fitted with Teflon-coated springs and silicone o-rings. To examine if there were possible deleterious effects to organisms resulting from collection through the spigots of Niskin bottles (e.g. from excessive turbulence or contamination), we performed experiments on 2 occasions with seawater collected by other means. On 31 March, all water used for the experiment (i.e. filtered and unfiltered) was collected by divers with acidcleaned polycarbonate carboys; time constraints did not permit a direct comparison to seawater collected with Niskin bottles on that day. On 2 April, 2 dilution experiments were run in which the unfiltered and filtered seawater for dilutions came from either Niskin bottles or from an acid-cleaned polyethylene bucket lowered over the side of the ship. The filtered seawater (FSW) for each of the 2 April experiments was made with separate filter units, Powder-free vinyl gloves were used for handling tubing and containers to limit contamination. FSW for dilutions was made by gravity-filtering through a closed system of 3.0 and $0.2 \mu \mathrm{m}$ Gelman pleated capsule filters connected with silicone tubing to a $50 \mu \mathrm{l}$ polyethylene carboy. The $3.0 \mu \mathrm{m}$ prefilter significantly reduced the time for filtering. All tubing and containers were first washed with Micro detergent (Baxter Diagnostics), rinsed with deionized water (Milli-Q or Nanopure), soaked in $10 \% \mathrm{HCl}$ overnight, and rinsed with deionized water (procedure modified from Fitzwater et al. 1982). The filter units were rinsed with $10 \mathrm{l}$ of deionized water, soaked in $10 \% \mathrm{HCl}$ for $1 \mathrm{~h}$, and rinsed with $10 \mathrm{l}$ of deionized water. In some cases, a filter unit was used for more than 1 experiment on successive days. In these cases, the filter units and tubing were rinsed with deionized water after use and stored at $4{ }^{\circ} \mathrm{C}$ after filling with a $300 \mathrm{ppm}$ sodium hypochlorite solution to prevent bacterial growth. Prior to an experiment, the hypochlorite solution was rinsed out of the filters with $10 \mathrm{l}$ of deionized water, followed by $10 \mathrm{l}$ of seawater. Appropriate amounts of FSW for each dilution were distributed to 201 polycarbonate carboys to prepare the dilutions prior to the collection of whole seawater. Whole seawater was collected from the Niskin bottles with silicone tubing placed at the bottom of a $50 \mathrm{l}$ carboy and distributed to the dilution carboys through acid-cleaned silicone tubing placed at the bottom of each dilution carboy, without the introduction of air bubbles. Subsamples were distributed with clean silicone tubing into $4 \mathrm{l}$ polycarbonate incubation bottles. Most water was collected before first light dur- $_{\text {- }}$ ing set-up, all bottles were kept darkened to reduce exposure to light prior to incubation. Incubation bottles were held for $24 \mathrm{~h}$ in an on-deck flowing seawater incubator, screened to the ambient light level with neutral density screening. 
Each experiment consisted of 4 or 5 dilution levels. Duplicate (March-April) or triplicate (October and August) bottles were filled at each dilution level; a control bottle with FSW was included to account for organisms that may have passed through the filter ( $\mathrm{Li}$ 1990). In a subset of experiments (October and August), a dilution series with the $<20 \mu \mathrm{m}$ size fraction was also run. To prepare the $<20 \mu \mathrm{m}$ fraction, seawater was gently filtered through a submerged, $20 \mu \mathrm{m}$ mesh, Nitex screen. We did not routinely prefilter the whole seawater through a $200 \mu \mathrm{m}$ mesh screen to remove larger grazers (e.g. Burkill et al. 1987, Gifford 1988), as copepod nauplii were relatively rare $\left(<10 \mathrm{l}^{-1}\right)$ and we wished to avoid damaging fragile protists or altering the natural mortality of the protists by larger grazers. However, for the $<20 \mu \mathrm{m}$ comparisons, we prefiltered the whole seawater through a $200 \mu \mathrm{m}$ mesh screen to mimic the extra handling step of the $<20 \mu \mathrm{m}$ treatment.

Nutrients (typically N, P, Mn and Fe) are sometimes added to dilution experiments (e.g. Landry \& Hassett 1982, Gallegos 1989, Landry et al. 1995a) to prevent nutrient depletion and maintain constant phytoplankton growth rates in all dilutions. Although nutrient levels in the surface waters of the oligotrophic Sargasso Sea are usually low (nM levels of nitrogen, e.g. Garside 1985, Brzezinski 1988, Glover et al. 1988, Lipshultz et al. 1996), phytoplankton biomass is also extremely low (typically less than $0.07 \mu \mathrm{g}$ chl $\mathrm{l}^{-1}$ ), which limits the potential for significant depletion in $24 \mathrm{~h}$ incubations. Therefore, we did not add nutrients routinely to the dilution experiments. Nutrient-amended experiments were included when chlorophyll biomass was unusually high (8 April) and when ambient nutrient levels were expected to be at their lowest (August). For nutrient-amended experiments, either f/2 (Guillard 1975) or MET-44 (Schöne \& Schöne 1982) nutrient mixtures were added to a final concentration of either ca 6 or $4 \mu \mathrm{M} \mathrm{NO}_{3}$ (April and August, respectively, see Table 2). The media were prepared with reagent grade chemicals according to the procedures developed by Brand et al. (1981) for culturing sensitive oceanic phytoplankton, except that primary vitamin stocks were filter-sterilized and stored frozen in acid-cleaned polyethylene tubes. In addition to nitrate, both media contain phosphate, silicate, iron, manganese, EDTA and vitamins. F/2 also contains zinc, cobalt, molybdenum and copper. Nutrient mixtures were added with the intent of supplying all possible limiting nutrients (Menzel \& Ryther 1961, Landry \& Hassett 1982).

Initial samples for chlorophyll analyses and cyanobacterial cell counts (August only) were taken in triplicate from each dilution; 1 sample for nutrient analyses also was taken from each dilution. After $24 \mathrm{~h}$, replicate samples for chorophyll and Synechococcus spp. cell counts (August only), and a single sample for nutrients, were taken from each incubation bottle. For chlorophyll determinations, either $460 \mathrm{ml}$ or 11 volumes were filtered onto $25 \mathrm{~mm} \mathrm{GF/F} \mathrm{filters.} \mathrm{The} \mathrm{filters} \mathrm{were}$ extracted into $10 \mathrm{ml}$ of $90 \%$ acetone at $-20^{\circ} \mathrm{C}$ overnight. Chlorophyll a was determined fluorometrically on a Turner Designs fluorometer. Nutrient samples were either analyzed on board ship with a Technicon Autoanalyzer (March cruise) or frozen and analyzed at Brookhaven National Laboratory (October cruise), using standard methods (Parsons et al. 1984). Nutrients were not analyzed on the August cruise. The level of detection for ammonium and nitrate with colorimetric methods is ca $0.03 \mu \mathrm{M}$, with a precision of ca $0.08 \mu \mathrm{M}$. Samples $(30 \mathrm{ml}$ ) for cyanobacterial cell counts were fixed with $1.0 \%$ glutaraldehyde, stored at $4^{\circ} \mathrm{C}$, and processed within $24 \mathrm{~h}$. Fixed samples were stained with DAPI ( $40 \mu \mathrm{g} \mathrm{ml}^{-1}$ ) and filtered onto $0.2 \mu \mathrm{m}$ black polycarbonate filters. Filters were mounted onto glass slides with low-fluorescing oil, sealed with paraffin, and stored frozen. A total of 300 to 400 cells was counted for each sample with a Zeiss epifluorescence microscope (1000× magnification, blue filter set 487709 ).

Net growth rates of chlorophyll and cyanobacteria were calculated in each dilution, assuming exponential growth $\left(k=1 / t \ln C_{t} / C_{0}\right.$, where $k=$ net growth rate, $t=$ time, $C_{l}=$ chlorophyll or cell count at time $t$, and $C_{0}$ $=$ initial chlorophyll or cell count). Instantaneous phytoplankton growth rate $(\mu)$ and grazing rate $(g)$ were calculated from the linear regression model of Landry \& Hassett (1982), where net growth rate is a function of dilution level $\left(D_{1}\right)$ as follows:

$$
k=\mu-g D_{l}
$$

The grazing rate, $g$, can be interpreted as the fraction of a volume of water cleared of chlorophyll-containing particles per day by the community of resident grazers (Frost 1980). It is directly proportional to $F$, the mean clearance rate of an individual grazer (volume grazer $\left.^{-1} \mathrm{~d}^{-1}\right)$ in the experiment $(F=V g / N$, where $N$ is the number of grazers and $V$ is the volume of the experimental container, Frost 1972). When $F$ is scaled to the concentration of grazers in the experimental container $(N / V)$, then:

$$
F^{*}=F N / V=g
$$

where $F^{*}$ is the community clearance rate (volume fraction cleared $\left.d^{-1}\right)$. Community ingestion rate $\left(I^{*}, \mu g\right.$ chl $\mathrm{I}^{-1} \mathrm{~d}^{-1}$ ) can be calculated as $I^{*}=g C=F^{*} C$, where $C$ is the ambient chlorophyll concentration. The relationship between community grazing rate and ingestion rate and ambient chlorophyll levels in the surface mixed layer was determined using nonlinear regression (Marquart-Levenberg algorithm, SigmaStat, Jandel Scientific, CA, USA). 


\section{RESULTS}

Table 2 summarizes the chlorophyll-based estimates of phytoplankton growth and grazing from 16 dilution experiments with unamended or $<200 \mu \mathrm{m}$ prescreened water from the surface mixed layer or deep chlorophyll maximum (DCM) and concurrent nutrient-amended and $<20 \mu \mathrm{m}$ size-fractionated experimental treatments on all 3 cruises. For experiments which did not yield statistically significant $(p>0.05)$ slopes, the mean net growth rate from all dilutions was used as an estimate of instantaneous growth rate $(\mu)$, assuming that grazing was neglible in these experiments. In unamended experiments, chlorophyllbased growth rates were variable, ranging from 0.2 to $0.8 \mathrm{~d}^{-1}$ (excluding data from 18 October, see below) and grazing rates ranged from not significant to $0.8 \mathrm{~d}^{-1}$. Grazing rate generally exceeded growth rate, although this difference was statistically significant in only a few cases. The trend of somewhat greater grazing than growth was consistent with the predominantly negative or near-zero values of net growth rate $(k)$ in undiluted samples (Figs. 1 to 3 ).

\section{March-April}

The March-April cruise was characterized by high hydrographic variability, which was reflected in large day-to-day variations in primary production, as well as in the biomass and composition of the phototrophic and heterotrophic plankton (Malone et al, 1993, Caron et al. 1995, Roman et al. 1995, Lessard \& Murrell 1996). High variability was also found in growth and grazing responses in dilution experiments (Table 2, Fig. 1). Prior to our arrival on 23 March, the water column was weakly stratified with a DCM at ca $60 \mathrm{~m}$, and the winter/spring bloom had begun (Michaels et al. 1994). There were seasonally elevated chlorophyll concentrations in both the surface mixed layer (up to $0.2 \mu \mathrm{g} \mathrm{l}^{-1}$ ) and the DCM (up to $1.2 \mu \mathrm{g} \mathrm{l}^{-1}$, but more typically $0.3 \mu \mathrm{g}$ $\left.\mathrm{l}^{-1}\right)$. Nitrate was below detection limits $(<0.03 \mu \mathrm{M})$ in surface waters and up to $0.3 \mu \mathrm{M}$ in the DCM; ammonium was detectable at all depths $(<0.2 \mu \mathrm{M})$.

During the cruise, we sampled from several different water masses (indicated as Phases) while following free-drifting sediment traps. When the first mixed layer and DCM experiments were performed $(25$ to

Table 2. Summary of chlorophyll growth $\left(\mu, \mathrm{d}^{-1}\right)$ and grazing $\left(g, \mathrm{~d}^{-1}\right)$ rates in dilution experiments in the northwestern Sargasso Sea in March-April and October 1990, and August 1991. Tmt = treatment; WW $=$ whole water with no amendments or prescreening $;$ +nut = nutrient amended $;<200 \mu \mathrm{m},<20 \mu \mathrm{m}=$ prescreening; $\mathrm{ML}=$ mixed layer; $D C M=$ chlorophyll maximum layer $;$ Chl = initial chlorophyll concentration. In the case of non significant regressions (i.e. slope, $g$, was not significantly different than zero, $p>0.05)$, mean net growth rate in all dilutions is included as an estimate of growth rate $(\mu)$, assuming grazing was negligible. ns: not significant

\begin{tabular}{|c|c|c|c|c|c|c|c|c|}
\hline Date & $\operatorname{Tm} t$ & Depth & Chl $\left(\mu \mathrm{gl}^{-1}\right)$ & $\mu$ & $95 \% \mathrm{Cl}$ & $g$ & $95 \% \mathrm{Cl}$ & $r^{2}$ \\
\hline 25 Mar 90 & WW & ML & 0.115 & 0.36 & 0.13 & 0.71 & 0.22 & 0.92 \\
\hline 27 Mar 90 & WW & DCM & 0.346 & 0.52 & 0.08 & 0.64 & 0.14 & 0.96 \\
\hline 29 Mar 90 & WW & DCM & 0.416 & 0.18 & 0.17 & 0.39 & 0.28 & 0.81 \\
\hline 31 Mar 90 & $W_{W}^{\text {a }}$ & $\mathrm{ML}$ & 0.240 & 0.29 & 0.08 & 0.71 & 0.14 & 0.96 \\
\hline 2 Apr 90 & $W_{W}^{a}$ & ML & 0.037 & 0.28 & 0.17 & ns & - & - \\
\hline 2 Apr 90 & WW & $\mathrm{ML}$ & 0.039 & $0.30^{\mathrm{b}}$ & 0.07 & ns & - & - \\
\hline 6 Apr 90 & WW & $\mathrm{DCM}$ & 0.281 & 0.26 & 0.17 & 0.28 & 0.26 & 0.66 \\
\hline 8 Apr 90 & WW & DCM & 1.045 & 0.75 & 0.15 & 0.83 & 0.25 & 0.94 \\
\hline 8 Apr 90 & WW+nut & DCM & 1.045 & 1.10 & 0.09 & 0.46 & 0.14 & 0.90 \\
\hline $13 \operatorname{Oct} 90$ & WW & ML & 0.048 & 0.46 & 0.17 & 0.50 & 0.26 & 0.59 \\
\hline 18 Oct 90 & WW & ML & 0.065 & 0.08 & 0.08 & 0.50 & 0.13 & 0.86 \\
\hline 20 Oct 90 & $<200 \mu \mathrm{m}$ & $M L$ & 0.059 & 0.43 & 0.11 & 0.40 & 0.20 & 0.69 \\
\hline 20 Oct 90 & $<20 \mu \mathrm{m}$ & ML & 0.059 & 0.39 & 0.07 & 0.29 & 0.11 & 0.77 \\
\hline 22 Oct 90 & $<200 \mu \mathrm{m}$ & ML & 0.071 & 0.29 & 0.21 & 0.53 & 0.33 & 0.55 \\
\hline 22 Oct 90 & $<20 \mu \mathrm{m}$ & $M L$ & 0.071 & 0.29 & 0.24 & 0.55 & 0.39 & 0.49 \\
\hline 10 Aug 91 & WW & ML & 0.066 & 0.19 & 0.18 & 0.47 & 0.27 & 0.53 \\
\hline 10 Aug 91 & $<20 \mu \mathrm{m}$ & ML & 0.065 & 0.13 & 0.19 & 0.43 & 0.29 & 0.94 \\
\hline 14 Aug 91 & WW & ML & 0.045 & 0.26 & 0.10 & 0.33 & 0.15 & 0.64 \\
\hline 14 Aug 91 & $W W+n u t$ & ML & 0.045 & 0.33 & 0.08 & ns & - & - \\
\hline 16 Aug 91 & WW & ML & 0.047 & 0.33 & 0.11 & 0.38 & 0.17 & 0.66 \\
\hline 16 Aug 91 & $W W+n u t$ & $\mathrm{ML}$ & 0.048 & 0.37 & 0.06 & ns & - & - \\
\hline 19 Aug 91 & WW & ML & 0.051 & 0.67 & 0.11 & 0.53 & 0.17 & 0.77 \\
\hline 19 Aug 91 & $W W+n u t$ & ML & 0.056 & 0.69 & 0.05 & ns & - & - \\
\hline
\end{tabular}



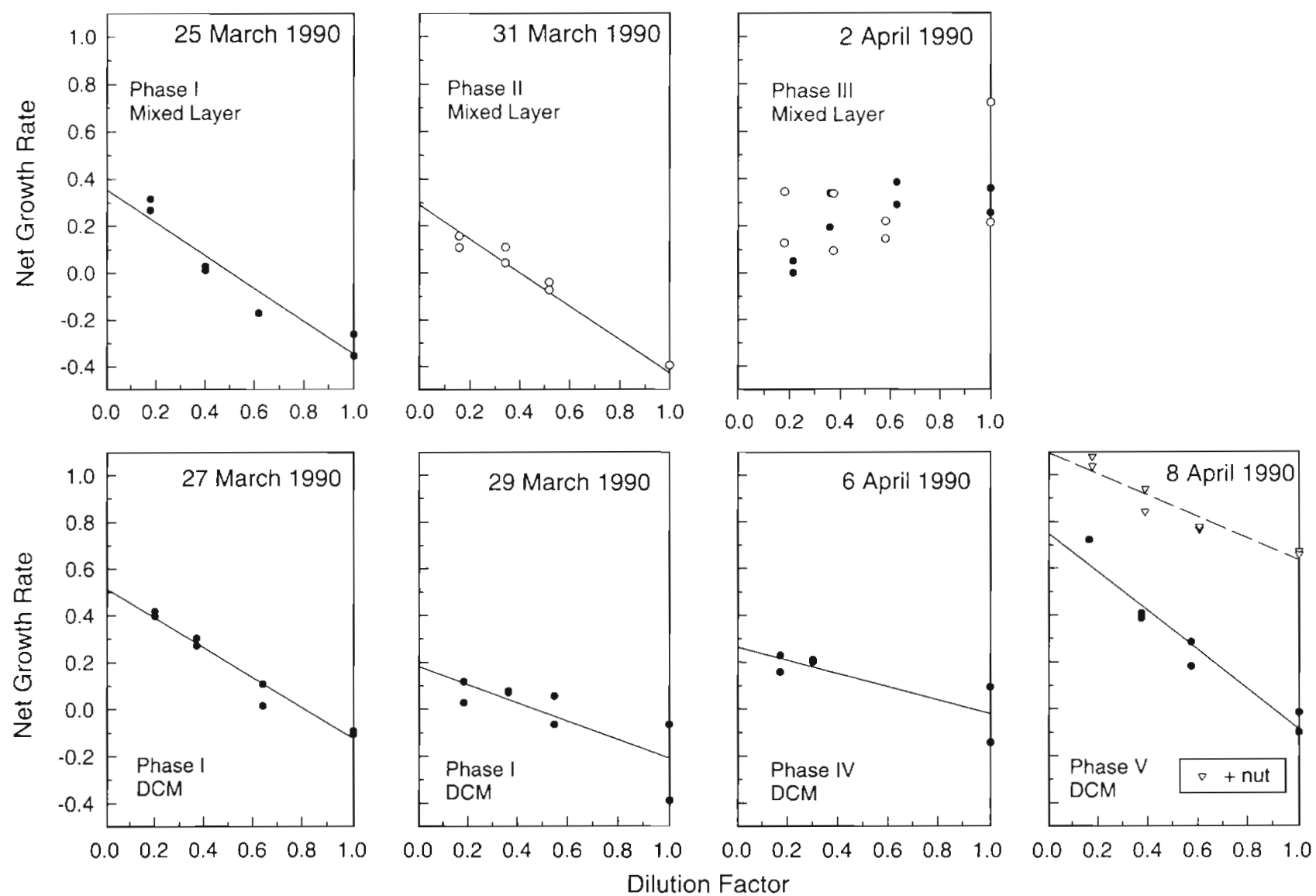

Fig. 1. Plots of chlorophyll net growth rate versus dilution factor from dilution experiments in March-April 1990 . (•) Niskincollected water; (0) carboy- (31 March) or bucket- (2 April) collected water. $(\nabla)$ Nutrient-amended treatments. (-) Least-square linear regression fits to the data
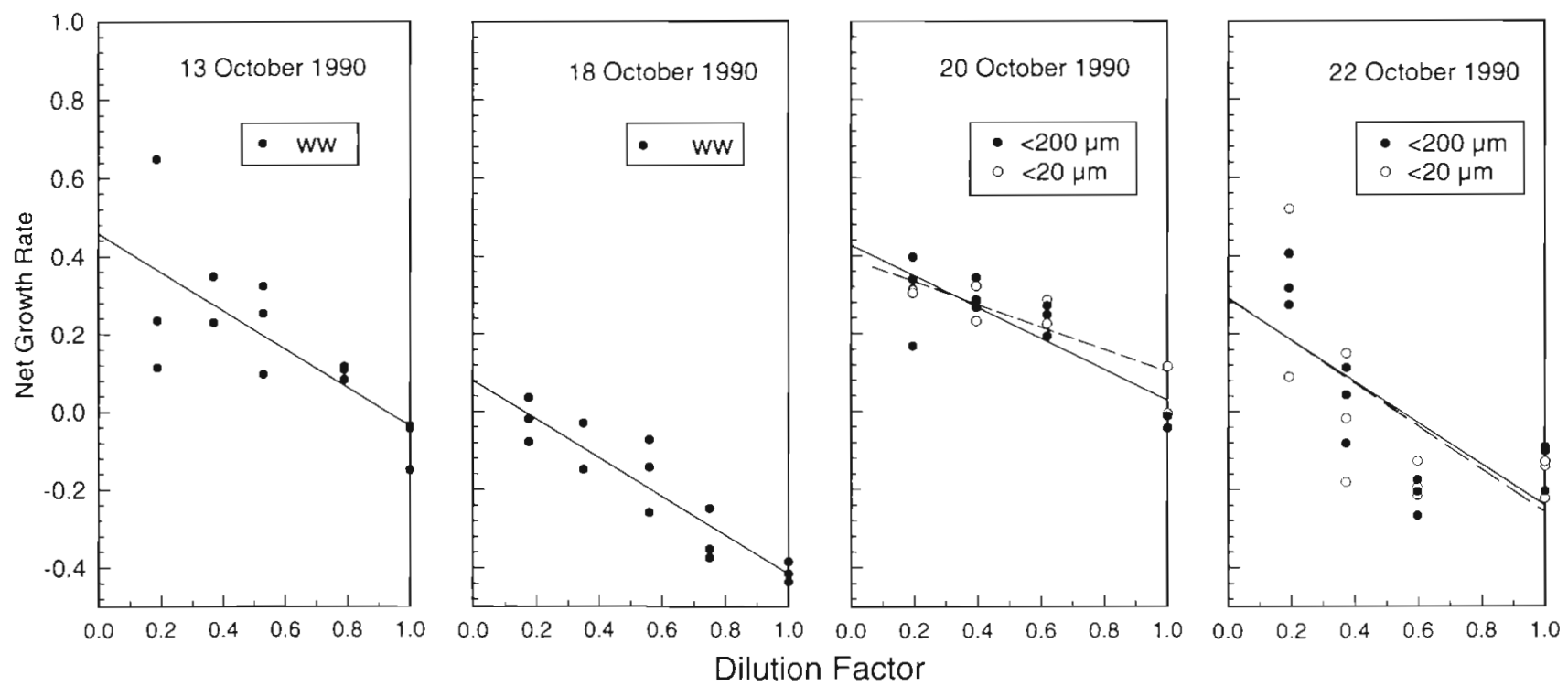

Fig. 2. Plots of chlorophyll net growth rate versus dilution factor from dilution experiments in October 1990. (•) Data from unfractionated or $<200 \mu \mathrm{m}$ sieved dilution treatments. (0) Data from treatments which had been prescreened through a $20 \mu \mathrm{m}$ mesh screen. (- - - - ) Least-square linear regression fits to the data 

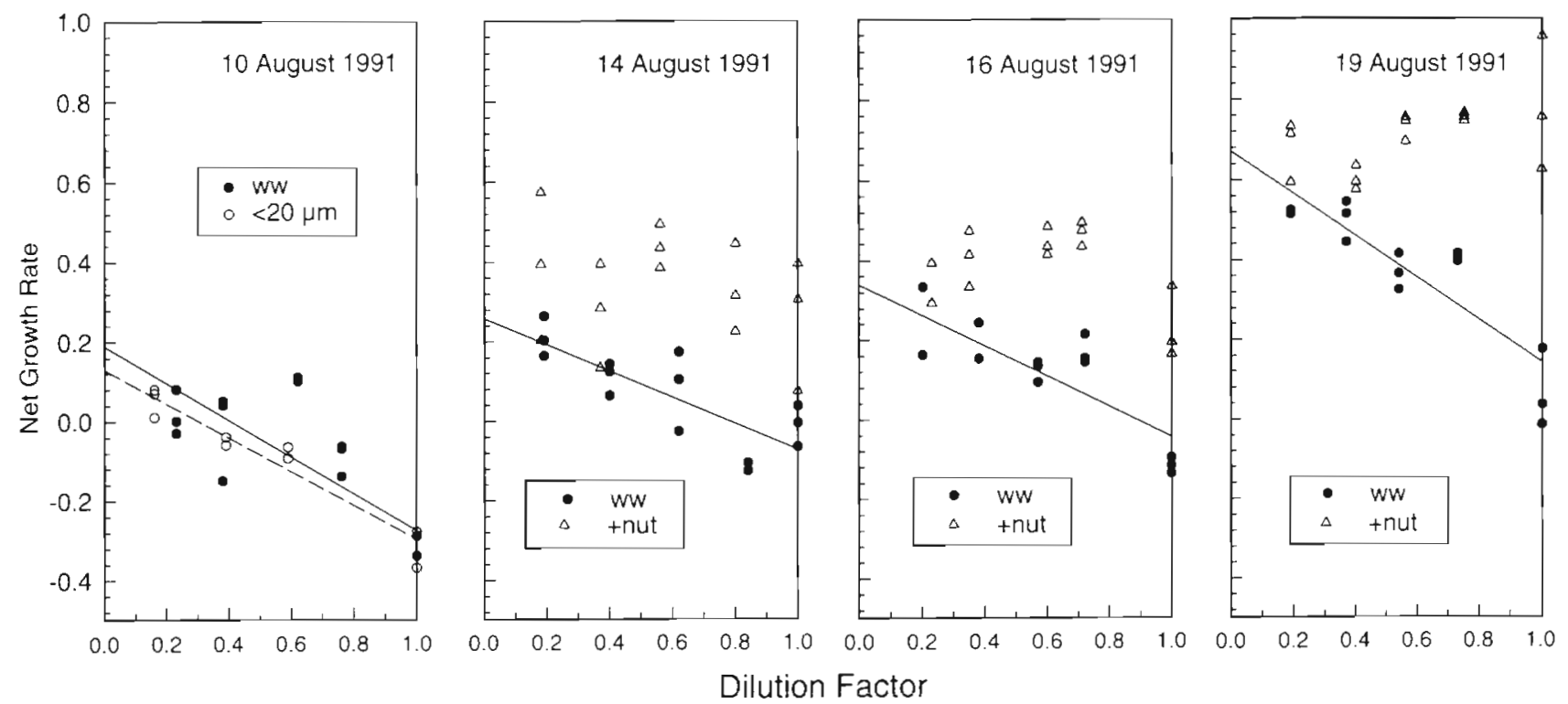

Fig. 3. Plots of chlorophyll net growth rate versus dilution factor from dilution experiments in August 1991. ( $\bullet$ ) Data from unfractionated, unamended dilution treatments. (O) Data from $<20 \mu \mathrm{m}$ prescreened dilution treatments. ( $\Delta$ ) Data from nutrientamended, unfractionated dilution treatments. (_, - - -) Least-square linear regression fits to the data

29 March, Fig. 1), the water column was weakly stratified, with a nitracline at ca $60 \mathrm{~m}$ (Phase I). Surface phytoplankton were predominantly cyanobacteria and prochlorophytes, while the DCM phytoplankton were primarily prochlorophytes and prymnesiophytes (inferred from HPLC pigments, Malone et al. 1993). Phytoplankton growth rate in the DCM $\left(0.5 \mathrm{~d}^{-1}\right)$ was somewhat higher than that in the mixed layer $\left(0.4 \mathrm{~d}^{-1}\right)_{i}$ there was measurable nitrate in the DCM at this time (27 March, Table 3; Lessard \& Murrell 1996). On 29 March, the nitracline had deepened slightly, nitrate was undetectable in the DCM (Table 3), and phytoplankton growth rate was reduced $\left(0.2 \mathrm{~d}^{-1}\right)$. Between 29 and 31. March (Phase II), a front with cooler surface water isothermal to $100 \mathrm{~m}$ moved through the area (Roman et al. 1995). The surface growth and grazing rates in this regime $\left(0.3\right.$ and $0.7 \mathrm{~d}^{-1}$, respectively) were similar to those on 25 March.

On 2 April, a warmer and more saline surface water mass moved through the area (Phase III). This change was accompanied by a dramatic decrease in productivity (less than one-half that on 29 March, Malone et al. 1993) and chlorophyll standing stock $\left(0.038 \mu \mathrm{g} \mathrm{l}^{-1}\right.$, one-third the earlier mean surface chlorophyll value of $0.14 \mathrm{hg} \mathrm{I}^{-1}$ ). On this day, 2 separate dilution experiments were performed with surface water collected either with Niskin bottles or with a clean bucket (see 'Methods'). In both experiments, net growth rates in all dilutions were positive, but the slopes of the dilution lines were not significantly different than zero (2 April, Fig. 1).
Table 3. Ammonium and nitrate concentrations $(\mu M)$ in dilution experiments at the start and end of $24 \mathrm{~h}$ incubations of water from the deep chlorophyll maximum in March-April 1990. Dilution level is expressed as fraction of unfiltered seawater. nd: no data; "Levels below the detection limit $(<0.03 \mu \mathrm{M})$

\begin{tabular}{|c|c|c|c|c|c|}
\hline \multirow[t]{2}{*}{ Experiment } & \multirow[t]{2}{*}{ Dilution } & \multicolumn{2}{|c|}{$\mathrm{NH}_{4}$} & \multicolumn{2}{|c|}{$\mathrm{NO}_{3}$} \\
\hline & & $T_{0}$ & $T_{2 A}$ & $T_{0}$ & $T_{24}$ \\
\hline \multirow[t]{5}{*}{27 Mar 90} & 1.0 & $0.28^{\circ}$ & 0.10 & $0.30^{3}$ & 0.19 \\
\hline & 0.6 & 0.23 & 0.14 & 0.25 & 0.19 \\
\hline & 0.4 & nd & 0.10 & 0.31 & 0.19 \\
\hline & 0.2 & 0.26 & 0.17 & 0.29 & 0.19 \\
\hline & 0.0 & 0.24 & nd & 0.31 & nd \\
\hline \multirow[t]{5}{*}{29 Mar 90} & 1.0 & $0.08^{\circ}$ & 0.03 & - & - \\
\hline & 0.6 & 0.09 & 0.08 & $\cdot$ & $\cdot$ \\
\hline & 0.4 & 0.15 & 0.14 & $\cdot$ & $\cdot$ \\
\hline & 0.2 & 0.13 & 0.14 & $\cdot$ & $\cdot$ \\
\hline & 0.0 & 0.11 & nd & $\cdot$ & $\cdot$ \\
\hline \multirow[t]{5}{*}{6 Apr 90} & 1.0 & 0.17 & 0.16 & . & • \\
\hline & 06 & 0.15 & 0.09 & $\cdot$ & • \\
\hline & 0.3 & 0.15 & 0.12 & - & • \\
\hline & 0.2 & 0.15 & 0.11 & $\cdot$ & • \\
\hline & 0.0 & 0.17 & nd & $\cdot$ & nd \\
\hline \multirow[t]{5}{*}{8 Apr 90} & 1.0 & 0.04 & 0.08 & 0.27 & $\cdot$ \\
\hline & 0.6 & 0.06 & 0.05 & 0.27 & - \\
\hline & 0.4 & 0.04 & 0.08 & 0.27 & $\cdot$ \\
\hline & 0.2 & 0.05 & 0.08 & 0.27 & 0.10 \\
\hline & 0.0 & 0.13 & nd & 0.27 & nd \\
\hline \multirow{4}{*}{$\begin{array}{l}8 \text { Apr } 90 \\
\quad(+ \text { nutrients })\end{array}$} & 1.0 & 0.22 & 0.16 & 5.90 & 4.62 \\
\hline & 0.6 & 0.45 & 0.20 & 5.94 & 5.02 \\
\hline & 0.4 & 0.42 & 0.13 & 6.26 & 5.50 \\
\hline & 0.2 & 0.42 & 0.13 & 6.28 & 5.73 \\
\hline
\end{tabular}

¿Value taken from vertical profile samples 
A non significant slope indicates that there was no measureable response of net phytoplankton growth rate to dilution. In the context of grazer feeding behavior theory, this result would occur if the prey concentrations over the dilution range were either at or below a threshold level where feeding efforts were reduced or stopped. (A non significant slope would also be expected if prey were at saturating levels at all dilutions, but saturated feeding is highly unlikely at these very low chlorophyll levels.) A toxic contaminant in the filtered seawater also could have produced a flat response, but typically leads to negative growth rates and a positive slope (e.g. Landry et al. 1995a) as the proportion of toxin increases with dilution. With the exception of the most dilute treatment in the Niskincollected experiment, net growth rates did not show a consistent decline with dilution. The seawater for these experiments came from shallower depths than previously ( $1 \mathrm{~m}$ and near-surface vs $10 \mathrm{~m}$ ) and thus would have been nearer to the ship. However, there was no evidence in the numerous primary productivity and other grazing measurements on this cruise that indicated toxicity in samples collected at $1 \mathrm{~m}$ compared to those at $10 \mathrm{~m}$ at this station or any other (Malone et al. 1993 and unpubl. data). The high net growth rates in the undiluted samples (mean $=0.3 \mathrm{~d}^{-1}$ Niskin, $0.4 \mathrm{~d}^{-1}$ bucket) also argues against toxic contamination; in almost all other experiments where grazing was measurable, the undiluted samples exhibited near-zero or negative net growth. Moreover, the net growth rates in the undiluted samples are very similar to the mean instantaneous growth rate of $0.3 \mathrm{~d}^{-1}$ estimated by the pigment-labeling method on this date for the mixed layer (Malone et al. 1993). The similarity between net and instantaneous growth rate estimates in undiluted samples is consistent with the idea that grazing was very low. For these reasons, it seems the most likely explanation for the flat dilution curves in these 2 experiments was low or negligible grazing.

The sampling on 6 April appeared to be in another different water mass (Phase IV); the surface water was warmer and more stratified than on the previous day. Phytoplankton growth in the DCM was relatively low $\left(0.3 \mathrm{~d}^{-1}\right)$, as it was on 29 March $\left(0.2 \mathrm{~d}^{-1}\right)$. On both sampling dates, the nitracline had deepened and nitrate was undetectable in the DCM. Grazing approximately balanced growth $\left(g=0.3 \mathrm{~d}^{-1}\right)$. Two days later, on 8 April, a warm eddy $\left(21.6^{\circ} \mathrm{C} \mathrm{SST}\right.$, sea surface temperature) passed through the study area (Phase V). The plankton assemblage in this water mass was more typical of slope water than subtropical oceanic water. Diatoms (Rhizosolenia spp., Chaetoceros spp., and Nitzschia sp.) dominated the elevated (>1 $\mu \mathrm{g} \mathrm{l}^{-1}$ ) chlorophyll biomass maximum at $42 \mathrm{~m}$. Large heterotrophic thecate dinoflagellates in the genera Protoperidinium and Diplopsalis (Lessard \& Murrell 1996) were present in unusually high numbers $\left(>5 \mathrm{ml}^{-1}\right)$ and dominated the microprotist biomass at this depth. These dinoflagellate species feed readily on large diatoms (e.g. Jacobson \& Anderson 1986) and were probably responsible for much of the grazing observed in this experiment. The highest growth rate of the cruise $\left(0.8 \mathrm{~d}^{-1}\right)$ was observed in this DCM. Grazing rate approximately balanced growth $\left(0.8 \mathrm{~d}^{-1}\right)$, but this rate may have been overestimated due to nutrient depletion (see below).

Nutrient levels were measured in all dilutions at the start and end of incubation. Nitrate was undetectable $(<0.03 \mu \mathrm{M})$ in 5 of the 7 experiments; nitrate was present at the level of $\mathrm{ca} 0.3 \mu \mathrm{M}$ in $2 \mathrm{DCM}$ experiments when the DCM occurred at the top of the nitracline $(27$ March and 8 April, Table 3). In the 27 March DCM experiment, which had a typical picoplankton-dominated phytoplankton, nitrate in all dilutions was drawn down but not depleted (Table 3). In the 8 April diatomdominated DCM experiment, nitrate was reduced below detection levels during the incubation. For reasons discussed below, the estimates of growth and grazing may have been affected by nutrient depletion in this experiment. Low levels of ammonium (ca 0.05 to $0.1 \mu \mathrm{M}$ ) were detected in most experiments and, bearing in mind the low precision of the method, did not appear to change over the course of the incubations. In the 27 March experiment, however, ammonium was somewhat elevated $(0.28 \mu \mathrm{M})$ and was reduced by about one-half over the incubation.

Deleterious effects to phytoplankton growth or microzooplankton grazing due to water collection with Niskin bottles was not evident. The 2 April experiment was a direct comparison of seawater collected with a Niskin bottle to that collected by bucket (Fig. 1). As mentioned earlier, no significant regression was obtained in either experiment. However, a comparison of mean net growth rate at each dilution did not show significant differences between the 2 treatments (paired $t$-test, $\mathrm{p}>0.05$ ). The $31 \mathrm{March}$ experiment used only carboy-collected water. Although not strictly comparable to the 25 March surface experiment performed with Niskin-collected seawater, the similarity in growth and grazing rates in the 2 experiments suggests that Niskin bottle collection was not harmful to phytoplankton or microzooplankton.

\section{October}

The October sampling was at stations north of Bermuda, south of the Gulf Stream at ca $36^{\circ} \mathrm{N}$. Water column characteristics were very similar to those at the BATS station in October (Michaels et al. 1994), except that nitrate was detectable in the surface water 
(ca $0.8 \mu \mathrm{M}$ ). The relatively high surface nitrate concentration could have been due to local storm mixing or proximity to the Gulf Stream; elevated nitrate also has been observed in the October-November period in some years at the BATS station (Michaels et al. 1994). Although surface nitrate was high, there was no indication of a bloom. Surface mixed layer chlorophyll levels were lower $\left(\right.$ mean $=0.05 \mu \mathrm{g} \mathrm{l}^{-1}$ ) than those during the spring cruise. The surface mixed layer was ca $60 \mathrm{~m}$ deep, and a DCM (mean $=0.22 \mu \mathrm{g} \mathrm{l}^{-1}$ ) was present between 80 and $100 \mathrm{~m}$. Primary production rates (mean $=325 \mathrm{mg} \mathrm{C} \mathrm{m}^{-2} \mathrm{~d}^{-1}$, data not shown) were similar to that found at the BATS station at this time of year (Lohrenz et al. 1992, Michaels \& Knap 1996), and most $(>80 \%$ ) of the productivity and chlorophyll was in the $<2 \mu \mathrm{m}$ size fraction (data not shown).

Growth rates in dilution experiments in surface waters ranged widely, from 0.1 to $0.5 \mathrm{~d}^{-1}$ (Table 2, Fig. 2), but grazing rates were more uniform $(0.4$ to $0.5 \mathrm{~d}^{-1}$ ). We suspect that the 18 October growth rate $\left(0.1 \mathrm{~d}^{-1}\right)$ was underestimated due to a change in the size of the GF/F filter (from 25 to $45 \mathrm{~mm}$ ) and an increase in filtration volumes between the initial and final samples for chlorophyll in this experiment. Therefore, final chlorophyll values may have been underestimated (causing net growth rates to be underestimated). If the underestimate was consistent between samples, instantaneous growth rate would be underestimated, but the grazing rate should still be valid. The strong regression $\left(r^{2}=0.86\right)$, and a grazing rate $\left(0.5 \mathrm{~d}^{-1}\right)$ which was very comparable to those found in the other experiments, suggest this was the case.

Ammonium levels in the dilution experiments were low $(<0.1 \mu \mathrm{M})$ and did not measurably change during the incubations in any of the experiments. Nitrate levels were high ( 0.7 to $1.1 \mu \mathrm{M})$ as previously mentioned, and showed little or no measurable change during incubation. These results are consistent with the low level of phytoplankton biomass and estimated growth rates. Given the low chlorophyll biomass (ca $0.06 \mu \mathrm{g} \mathrm{l}^{-1}$ ) and observed growth rates (ca 0.5 doublings $\mathrm{d}^{-1}$ ), the nitrogen needed to support this growth (assuming a C:chl ratio of 50 , and a C:N ratio of 7, Malone et al. 1993), was on the order of $30 \mathrm{nM}$, which is below the precision of the nutrient analysis methods used.

\section{August}

On this cruise, as in March-April, we sampled in the vicinity of the BATS station. At this time of the year, prymnesiophytes and cyanobacteria predominate in the surface water, and prochlorophytes are relatively rare (Olsen et al. 1990, Goericke \& Welschmeyer 1993, R. Goericke pers. comm.). At the surface depths where experiments were performed, the $<2 \mu \mathrm{m}$ fraction was 65 to $88 \%$ of the total chlorophyll. Cyanobacteria contributed ca $30 \%$ to total chlorophyll in the surface water on 16 August, based on HPLC pigment analysis (R. Goericke pers. comm.), corresponding to ca $2 \mathrm{fg} \mathrm{chl} \mathrm{cell}{ }^{-1}$. Applying this conversion, we estimated that cyanobacteria contributed ca. 18, 22 and $35 \%$ of the total chlorophyll in the 10,14, and 19 August experiments, respectively.

In the first 3 experiments, chlorophyll-based growth rates in the surface water ranged from 0.2 to $0.3 \mathrm{~d}^{-1}$; grazing rates $\left(0.3\right.$ to $\left.0.5 \mathrm{~d}^{-1}\right)$ equaled or exceeded growth (Table 2, Fig. 3). In the last experiment, surface temperature was more than $2^{\circ} \mathrm{C}$ cooler than in the preceding $9 \mathrm{~d}$, indicating possible mixing or water mass change. Growth rate in this experiment was substantially higher $\left(0.7 \mathrm{~d}^{-1}\right)$ and net growth in the undiluted samples was positive (Table 2).

In these experiments, we also estimated the growth and grazing of cyanobacteria. Cyanobacterial numbers at the start of the experiments ranged from 5 to $9 \times$ $10^{3} \mathrm{ml}^{-1}$ (Table 4). The 10 August experiment did not yield a significant regression (however, excluding data from the highest dilution, the growth and grazing estimates were 0.8 and $0.3 \mathrm{~d}^{-1}$, respectively, $p<0.05$ ). In all 4 experiments, cyanobacterial net or instantaneous growth rates $\left(0.5\right.$ to $\left.0.9 \mathrm{~d}^{-1}\right)$ exceeded that of total chlorophyll (Table 4, Fig. 4). Also, in contrast to rates based on total chlorophyll, grazing rates of cyanobacteria were lower than growth rates (Table 4). Consistent with this imbalance, cyanobacteria numbers increased over the sampling period (Table 4). Imbalances between growth and grazing of cyanobacteria in oligotrophic oceans have been observed before using a variety of techniques (e.g. Campbell \& Carpenter 1986b, Iturriaga \& Mitchell 1986, Iturriaga \& Marra 1988).

Table 4. Summary of cyanobacterial growth $\left(\mu_{1} \mathrm{~d}^{-1}\right)$ and grazing rates $\left(g, d^{-1}\right)$ in dilution experiments in the mixed layer in August, 1991. Tmt $=$ treatment; $w w=$ whole water with no amendments or prescreening + nut $=$ nutrient amended. No. $\mathrm{ml}^{-1}=$ initial cyanobacterial abundance ns: not significant

\begin{tabular}{|llcccccc|}
\hline Date & Tmt & No. ml & $\mu$ & $95 \% \mathrm{Cl}$ & $g$ & $95 \% \mathrm{CI}$ & $\mathrm{r}^{2}$ \\
\hline 10 Aug 91 & WW & $6 \times 10^{3}$ & 0.55 & 0.28 & $\mathrm{~ns}$ & - & - \\
10 Aug 91 & $<20 \mu \mathrm{m}$ & & 0.71 & 0.11 & $\mathrm{~ns}$ & - & - \\
14 Aug 91 & WW & $5 \times 10^{3}$ & 0.87 & 0.10 & 0.20 & 0.15 & 0.38 \\
14 Aug 91 & WW+nut & & 0.22 & 0.05 & $\mathrm{~ns}$ & - & - \\
16 Aug 91 & WW & $7 \times 10^{3}$ & 0.54 & 0.13 & 0.33 & 0.18 & 0.52 \\
16 Aug 91 & WW+nut & & 0.27 & 0.08 & ns & - & - \\
19 Aug 91 & WW & $9 \times 10^{3}$ & 0.75 & 0.16 & 0.28 & 0.23 & 0.56 \\
19 Aug 91 & WW+nut & & 0.23 & 0.06 & ns & - & - \\
\hline
\end{tabular}



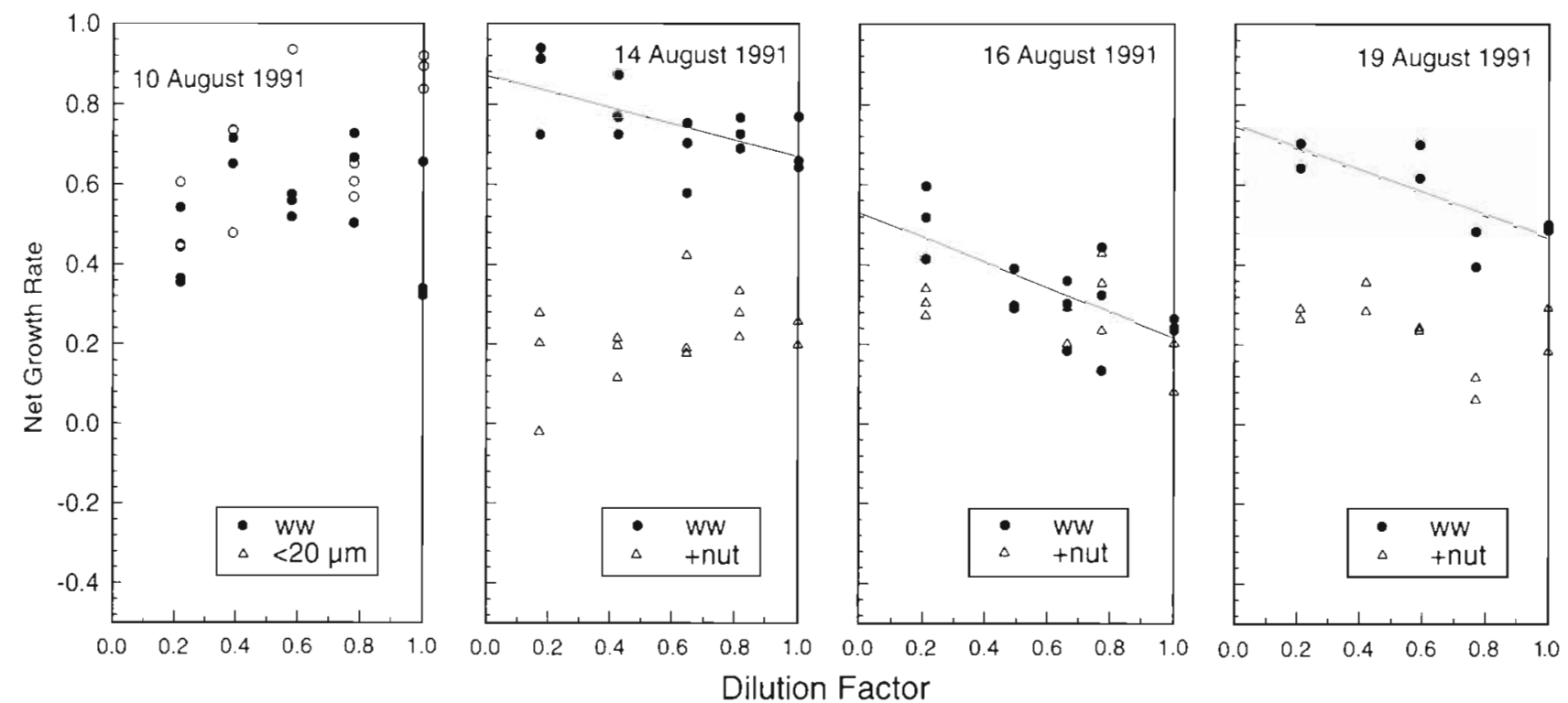

Fig. 4. Plots of cyanobacteria net growth rate versus dilution factor from dilution experiments in August 1991. Symbols and lines as in Fig. 3

Temporal decoupling of cyanobacteria growth and grazing may explain the observed imbalance. Cyanobacteria appear to respond preferentially and quickly (within $1 \mathrm{~d}$ ) to natural transient nitrate pulses with increased growth rates and cell abundances, which are quickly grazed down over subsequent days (Glover et al. 1988).

\section{Effects of nutrient additions}

In general, chlorophyll net growth rates increased but grazing rates and cyanobacterial net growth rates decreased in the nutrient-amended experiments (Figs. 1, $3 \& 4$, Table 2). The reduction in grazing and cyanobacterial growth rates indicates that some component or contaminant in the nutrient mixtures was harmful. It is therefore difficult to draw conclusions from the nutrient-amended experiments.

However, it is interesting to note that the reduction in grazing rate was much less severe (grazing coefficient was significant) in the nutrient-amended experiment from the spring DCM than in the summer surface layer. This suggests that either the grazers in the 8 April DCM were less sensitive to the nutrient additions (perhaps due to their more coastal origin) or the deleterious component was absent in that batch of nutrient media. Given the high biomass ( $>1 \mu \mathrm{g} \mathrm{chl} \mathrm{^{-1 }}$ ) and nitrate depletion which occurred in the unamended incubations, the observed results also could have been caused by differential nutrient limitation. More severe nutrient limitation in the least dilute samples with higher biomass would exaggerate the slope of the dilution line. Estimates of growth rate from the observed nitrate utilization in the unamended series (using a depth-specific C:chl ratio of 32 and C:N molar ratio of 6. Malone et al. 1993) suggested that growth rate in the undiluted treatment was lower than in the most dilute treatment $\left(0.5\right.$ and $1.0 \mathrm{~d}^{-1}$, respectively). If grazing rate in the amended experiment was unaffected by nutrient additions, then growth rate in the most dilute and undiluted treatments can also be estimated from the relationship $\mu=k+g D_{j}$, where $g$ is the nutrientamended grazing rate (Andersen et al. 1991, Landry et al. 1995a). That these estimates (0.4 and $0.8 \mathrm{~d}^{-1}$, respectively) are close to those estimated from nitrate utilization is consistent with the interpretation that grazing rate in the 8 April unamended experiment was exaggerated due to nutrient depletion and suggests that the nutrient-amended grazing rate may not have been negatively affected by nutrient additions. If this interpretation is correct, the nutrient-amended grazing rate may be more accurate and would indicate that growth was not balanced by grazing in this diatomdominated DCM.

\section{$<20 \mu \mathrm{m}$ size fractionation}

In 2 experiments in October and 1 in August, we compared growth in dilution experiments with whole seawater (or $<200 \mu \mathrm{m}$ ) to that of $<20 \mu \mathrm{m}$ size fractionated seawater to determine the contribution of the $<20 \mu \mathrm{m}$ grazers to total grazing. In both the October 
and August experiments, there was no significant difference $(p>0.05)$ in the slope of the regressions between the $<200 \mu \mathrm{m}$ size fraction and the $<20 \mu \mathrm{m}$ size fraction, supporting the idea that most of the grazing can be attributed to grazers $<20 \mu \mathrm{m}$ in size.

\section{DISCUSSION}

The dilution technique (Landry \& Hassett 1982) is now commonly used to estimate community growth and grazing rates, although it has primarily been applied to mesotrophic and eutrophic environments (e.g. Burkill et al. 1993, Kamiyama 1994a, Landry et al. 1995a). There has been much discussion in the literature about the potential responses of phytoplankton and grazers to dilution, and what effect these responses might have on experimental results and their interpretation (e.g. Landry \& Hassett 1982, Gifford 1988, Gallegos 1989, Andersen et al. 1991, Evans \& Paranjape 1992, Landry et al. 1993, Neuer \& Cowles 1994). As Landry et al. (1993) point out, dilution experiments are conceptually simple but interpretation of their results can be complicated. Since this is one of the first reports applying the dilution technique in extremely oligotrophic conditions, further discussion is warranted on how 2 potential problems may have affected the dilution experiments, namely (1) nonconstant phytoplankton growth rates due to nutrient depletion during incubation and (2) threshold feeding behavior of grazers.

\section{Nutrient limitation of growth rates}

Nutrient depletion during incubation could lead to an underestimate of growth rate. If depletion occurs to the same degree in all dilutions, growth rate may be underestimated but the grazing rate (regression slope) should not be affected. Differential depletion of a nonrecycled limiting nutrient (e.g. nitrate) in less dilute samples with higher phytoplankton biomass would exaggerate the slope of the regression and overestimate grazing rates. This generally would lead to an underestimate of growth rate, but could also lead to an overestimate in the case of severe limitation (e.g. Landry \& Hassett 1982). Depletion of a recycled limiting nutrient (e.g. ammonia or iron) would occur to a greater degree in the highest dilution with the fewest grazers; this would have the effect of lowering the slope of the regression and underestimating both grazing and growth rates. To obviate these complications, excess nutrients are sometimes added to achieve constant phytoplankton growth rates in all dilutions (e.g. Landry \& Hassett 1982, Gallegos 1989. Landry et al. 1995a).

We did not add nutrients routinely to the dilution experiments because phytoplankton biomass in the Sargasso Sea is very low (typically less than $0.07 \mathrm{\mu g} \mathrm{chl}$ $\left.\mathrm{l}^{-1}\right)$, which limits the potential for significant nutrient depletion in $24 \mathrm{~h}$ incubations. We were also concerned with possible deleterious effects of added nutrients or trace contaminants in nutrient stocks to potentially sensitive protists (Landry \& Hassett 1982, Gifford 1988). The results of our nutrient-amended experiments indicated that detrimental effects did occur with the nutrient mixtures, at least in the summer surface mixed layer experiments. Therefore, we cannot say with certainty whether or not nutrient depletion was occurring in the unamended experiments. To the extent that there may have been incubation-induced limitation, the unamended growth rates will be underestimates.

Despite the potential for underestimating growth rates from possible nutrient depletion, chlorophyll growth rates estimated from unamended dilution experiments were relatively high (in the range of 0.2 to $0.8 \mathrm{~d}^{-1}$ ) and do not appear to be grossly underestimated. These rates are higher than once thought to occur in the oligotrophic ocean (e.g. Eppley 1980), but not as high as those observed in the North Pacific central gyre (Laws et al. 1987) or near the maximum predicted by the Eppley temperature curve (Banse 1995). They are very comparable to other estimates for Sargasso Sea phytoplankton using the ${ }^{14} \mathrm{C}$-chlorophyll labeling technique (Table 5). Cyanobacteria growth rates in unamended dilution experiments in the surface mixed layer water in August were high $(0.5$ to $0.9 \mathrm{~d}^{-1}$, and very similar to cyanobacteria growth rates in the Sargasso Sea estimated by a variety of other methods (Table 5). Thus, the growth rates from our dilution experiments appear to be reliable estimates

Table 5. Growth rates of phytoplankton in the Sargasso Sea estimated with different methods

\begin{tabular}{|c|c|c|c|}
\hline & $\mu\left(\mathrm{d}^{-1}\right)$ & Method & Source \\
\hline Phytoplankton & $\begin{aligned} & 0.3-0.6 \\
< & 0.1-1.3 \\
< & 0.1-0.8^{\circ} \\
& 0.2-0.8\end{aligned}$ & $\begin{array}{l}\text { Pigment labeling } \\
\text { Pigment labeling } \\
\text { Pigment labeling } \\
\text { Dilution technique }\end{array}$ & $\begin{array}{l}\text { Taguchi et al. (1988) } \\
\text { Malone et al. (1993) } \\
\text { Goericke \& } \\
\text { Welschmeyer (1993) } \\
\text { This study }\end{array}$ \\
\hline Cyanobacteria & $\begin{array}{l}0.5-1.2 \\
0.4-0.9 \\
0.5-0.9\end{array}$ & $\begin{array}{l}\text { Track autoradiography } \\
\text { FDC } \\
\text { Dilution technique }\end{array}$ & $\begin{array}{l}\text { Iturriaga \& Marra (1988) } \\
\text { Campbell \& Carpenter } \\
\text { (1986a) } \\
\text { This study }\end{array}$ \\
\hline
\end{tabular}


and they add to the accumulating data set of moderately, but not exceptionally, high phytoplankton growth rates in the Sargasso Sea.

\section{Nonlinear feeding behavior}

The standard dilution model (Landry \& Hassett 1982) assumes a linear decrease in consumption rates with increasing dilution. This model is based on the supposition that individual grazer clearance rates, and relative grazer densities, remain constant over the range of prey concentrations created by dilution over the incubation period. If the functional feeding response is nonlinear (i.e. clearance rates change over the range of prey concentration) and/or the dilution range includes saturating or threshold concentrations, applying a linear model can result in errors in parameter estimates (Gallegos 1989, Evans \& Paranjape 1992). At the extremely low biomass levels found in the Sargasso Sea, saturated feeding is highly unlikely, but threshold behavior might be expected. If the ambient phytoplankton density is at or near the threshold level where a reduction or cessation of feeding occurs, then further dilution will not result in an increase in net growth rate. This situation would manifest itself as a flat (nonsignificant slope) dilution curve. If ambient phytoplankton density is above a threshold level but is diluted below it, the dilution curve would flatten at the highest dilutions (Gifford 1988, Gallegos 1989).

In our data set, flat dilution curves were found when ambient chlorophyll was at a minimum (2 April, Fig. 2), suggesting a possible threshold. In experiments where the ambient chlorophyll was diluted below this level, however, a flattening at high dilutions was not consistently observed, although there was an indication of flattening in about one-half of the surface (unamended) experiments (Figs. 1 to 3 ). As with typical dilution experiment data (Evans \& Paranjape 1992), though, the sample points are too few and variable to allow a definitive conclusion about the presence or absence of nonlinear or threshold behavior within a dilution experiment.

That there may have been nonlinear and threshold feeding responses occurring in situ was suggested when we examined the relationship between community grazing rates and ambient chlorophyll levels in the mixed layer. (The relationship would be different in the DCM due to differences in C:chl ratio, but the DCM data were too limited to consider.) Over the observed seasonal range in surface chlorophyll, community grazing rates $(g)$ were maximal at the highest concentrations of chlorophyll and steeply declined below ca $0.1 \mu \mathrm{g} \mathrm{chl}^{-1}$ (Fig. 5A). Note that, if there were no change in grazer biomass over this concentration range, a linear functional feeding model (Type 1) would predict that $g$ remains constant and a hyperbolic model without a threshold (Type 2) would predict an increasing $g$ with decreasing chlorophyll concentration. A threshold chlorophyll level was apparent, whether or not data from experiments with apparent zero grazing rates (non significant slopes) were included. The relationship between community grazing rate $\left(g\right.$ or $\left.F^{*}\right)$ and food concentration could be described with a Michaelis-Menten model with a feeding threshold:

$$
g=\frac{I^{*}}{C}=\frac{I_{\max }^{*}\left(C-C_{0}\right)}{k+\left(C-C_{0}\right)} \frac{1}{C}
$$

where $I^{*}$ max is the maximum community ingestion rate, $k$ is a constant, $C$ is chlorophyll concentration and $C_{0}$ is the $x$ intercept or threshold chlorophyll concentration.
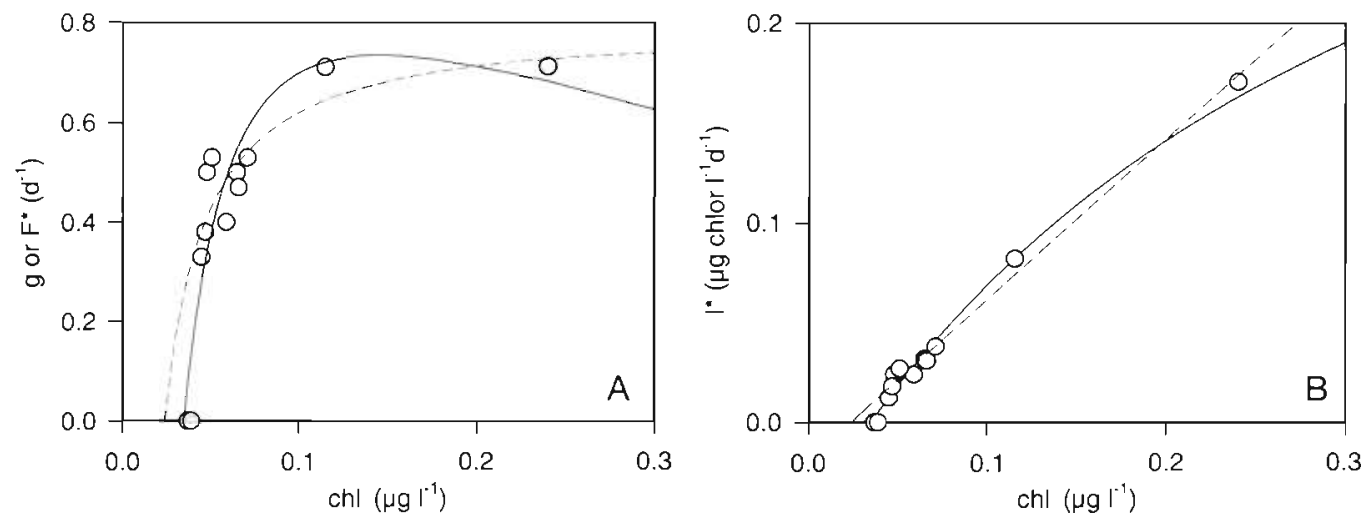

Fig. 5. Community grazing and ingestion rates of the natural grazer assemblages in the Sargasso Sea plotted against ambient surface chlorophyll concentrations. Each point represents the grazing or ingestion rate from a single experiment. (A) Community grazing or clearance rate $\left(g\right.$ or $\left.F^{*}\right)$ plotted against ambient chlorophyll concentration. $(-)$ Best-fit curve $\left(\mathrm{r}^{2}=0.83\right)$ using the Michaelis-Menten model with a threshold (in text). (-- ) Best-fit curve $\left(r^{2}=0.75\right)$ excluding the zero grazing rate data (0) (B) Community ingestion rates $\left(I^{*}\right)$ plotted against ambient chlorophyll concentration. (-, - - ) Michaelis-Menten model curves generated with parameters derived from the curve fits in (A) 
A nonlinear fit using the above model and including data from all surface experiments yielded a threshold chlorophyll concentration $\left(C_{0}\right)$ of $0.035 \mu \mathrm{g} \mathrm{chl} \mathrm{l^{-1 }}(95 \%$ confidence limits: 0.030 to $0.040 \mu \mathrm{g} \mathrm{chl} \mathrm{l}^{-1}, \mathrm{r}^{2}=0.83$ ). If the data without significant slopes were excluded, the threshold concentration was $0.024 \mu \mathrm{g} \mathrm{chl} \mathrm{l^{-1 }} 195 \%$ confidence limits: 0.018 to $0.031, r^{2}=0.75$ ). Ingestion rates (calculated from $I^{*}=g C$ ) increased with chlorophyll concentration above the threshold value (Fig. 5B), as predicted by the Michaelis-Menten model.

It is instructive to examine what a dilution experiment would look like if grazers behaved according to the above model and ambient chlorophyll was diluted below the threshold. For this simulation, a time-dependent dynamic model (courtesy of B. Frost) was used to predict the net apparent phytoplankton growth rate $(k)$ in each dilution of an experiment with ambient chlorophyll of $0.045 \mathrm{\mu g}^{-1}$. A representative grazer biomass (3.5 $\left.\mu \mathrm{g} \mathrm{C} \mathrm{I}^{-1}\right)$ and phytoplankton growth rate $\left(0.4 \mathrm{~d}^{-1}\right)$ were used, and grazers were assumed to not grow during the experiment. Calculations were made at hourly intervals to take into account changes in phytoplankton concentration due to growth and grazing. The resulting plot of model data sampled at typical dilutions (Fig. 6) shows that even though chlorophyll was diluted below the threshold, flattening of the curve is strongly apparent only at the highest dilution, and the data fit a linear model well. It is interesting to note that the predicted results are consistent with experimental results. As in the experiments, net growth rate in the

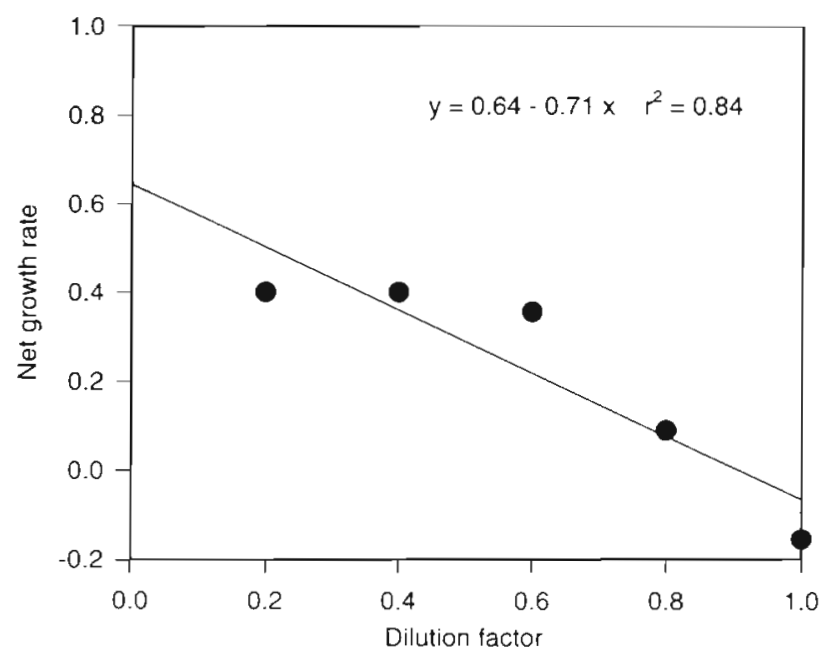

Fig. 6. Simulated dilution experiment results using a timedependent dynamic model to predict phytoplankton net growth in each dilution, assuming grazer behavior followed the Michaelis-Menten model described in Fig. 5. Ambient chlorophyll was $0.045 \mu \mathrm{g} \mathrm{l}^{-1}$, grazer biomass was $3.5 \mu \mathrm{g} \mathrm{Cl}^{-1}$ and phytoplankton specific growth rate was $0.4 \mathrm{~d}^{-1}$ (see text for further explanation). (-) Least-square regression fit to the sampled data points undiluted sample was somewhat negative $\left(-0.15 \mathrm{~d}^{-1}\right.$ in the nonlinear model, $-0.07 \mathrm{~d}^{-1}$ from the linear fit), indicating that grazing slightly exceeded growth. A linear fit to the sampled model data overestimates both growth rate $\left(0.64\right.$ vs $\left.0.40 \mathrm{~d}^{-1}\right)$ and grazing rate $(0.71$ vs $0.55 \mathrm{~d}^{-1}$ ). If grazing rates were overestimated in the experiments, this would have affected the parameter values of the functional feeding model, but not necessarily the form. This extreme example (near-threshold ambient chlorophyll, nonlinear feeding behavior) serves to further emphasize that in a real experiment with typical replicate sample variability, it would be difficult to resolve threshold behavior. Increasing replication and dilution levels and including an independent measure of grazing (e.g. FLB disappearance, Landry et al. 1995b) at each dilution may help to resolve whether nonlinear and/or threshold behavior is occurring in dilution experiments in oligotrophic systems.

\section{Ecological implications}

The dilution experiment results indicate that there was substantial grazing of phytoplankton biomass by microzooplankton at most times of the year in the Sargasso Sea. There was considerable day-to-day variability in the magnitude and balance of growth and grazing rates, which could in part be ascribed to changes in the plankton assemblages as eddies and fronts moved through the sampling area. High variability in phytoplankton growth rates measured with other methods has been observed previously in the Sargasso Sea and the North Pacific central gyre (Laws et al. 1987, Goericke \& Welschmeyer 1993, Malone et al. 1993). Comparable data sets are not available for microzooplankton grazing rates in other oligotrophic gyres, but high day-to-day variability in grazing rates has been noted in the Equatorial Pacific (Landry et al. 1995a). In our study, chlorophyll-based grazing rates approximately balanced growth rate in about one-half of the unamended experiments and exceeded it in about one-third of the experiments (Table 2). In the majority of the experiments, net growth in undiluted treatments was negative. In March-April, this imbalance was consistent with the observed temporal pattern in chlorophyll standing stock in the BATS area. At the time of our sampling, the peak in productivity and chlorophyll standing stock at the BATS station was past (Michaels et al. 1994), and we were sampling during the decline of the spring bloom. The high frequency of negative net growth in undiluted seawater over the entire data set is somewhat unusual compared to that found in other dilution experiment studies performed in higher biomass environments (e.g Gifford 1988, Strom \& Welschmeyer 1991, Kamiyama 1994, 
Landry et al. 1995a), but not unique (e.g. Landry et al. 1993, Verity et al. 1996). Of course, most dilution experiment studies, including this one, take a very small sample of a heterogeneous environment, where on any given day or place growth and grazing could be balanced or unbalanced. Insofar as the dilution experiment results are representative and reliable, they provide evidence that phytoplankton growth is closely balanced by grazing at most times of the year in the Sargasso Sea.

The approximate balance between growth and grazing is not unexpected. Grazing balance appears to account for the relative constancy in chlorophyll in various oceanic regions where small phytoplankton are growing at high, but nutrient-limited submaximal, rates (e.g. Landry et al. 1997). However, it is not clear what mechanisms determine the minimum level of steady-state phytoplankton biomass (e.g. surface mini-

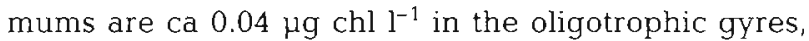
ca $0.2 \mu \mathrm{g} \mathrm{chl} \mathrm{l}^{-1}$ in the subarctic Pacific). While nutrient supply (macro or micro) clearly regulates phytoplankton growth rate, it may not directly determine the minimum level of steady-state phytoplankton biomass. Evidence for this may be found in large-scale, longterm (greater than days to weeks) natural 'experiments' which cause significant interannual variation in nutrient inputs to the oligotrophic gyres. Increases in macronutrient availability during El Niño Southern Oscillation events, for example, produce significant increases in primary production, but phytoplankton standing stock remains at the same level in the North Pacific gyre (Karl et al. 1995) or exhibits only very small springtime increases that return to previous steady-state levels upon summer stratification in the North Atlantic gyre (Michaels \& Knap 1996). Dynamic plankton models for both the oligotrophic North Atlantic (Sarmiento et al. 1993) and the Pacific equatorial upwelling zone (Frost \& Franzen 1992) have demonstrated that in the presence of grazers, supply of a limiting nutrient (macro or micro) alone cannot account for steady state chlorophyll levels. Without a lower phytoplankton biomass limit, most dynamic models of ecosystem behavior are unstable (Steele 1974, Steele \& Henderson 1992). This lower limit is established in models usually by including threshold feeding behavior by the zooplankton, by which grazing effort is reduced or absent below a certain concentration of phytoplankton where it may be energetically disadvantageous to continue feeding efforts (e.g. Steele 1974, Frost \& Franzen 1992). Alternatively, the limit has been set by invoking switching behavior, in which zooplankton feed preferentially on the most abundant prey; in essence, this creates a threshold for the phytoplankton when less abundant than other prey (Fasham et al. 1990). Thus, in theory, feeding threshold behav- ior is critical to ecosystem stability, but its existence has not been demonstrated in natural communities.

Feeding threshold behavior has been frequently observed in laboratory experiments with crustacean zooplankton (e.g. Frost 1975, Paffenhöfer 1988). Laboratory evidence for feeding thresholds in protists, however, is more equivocal. Feeding thresholds have been demonstrated for some bacterivorous protists (e.g. Rivier et al. 1985, Choi 1994. Eccleston-Parry \& Leadbeater 1994). However, similar experiments with other bacterivorous (e.g. Sherr et al. 1983, Anderson 1988/89) and herbivorous protists (e.g. Heinbokel 1978, Stoecker 1988, Strom \& Buskey 1993) have shown that protist feeding efforts (i.e. clearance rates) increase continuously as phytoplankton prey decreases, calling into question the existence of threshold feeding behavior in protists in nature. Protist behavior in laboratory experiments, which often require artificially high protist/prey ratios, however, may not reflect natural behavior. The data presented here suggest that threshold behavior may exist in natural assemblages of herbivorous protists

The response of community clearance and ingestion rates to food abundance (Fig. 5) could have been the result of either changes in grazer biomass and/or changes in feeding behavior. The size-fractionated dilution experiments indicated that the major grazers were $<20 \mu \mathrm{m}$ in size; heterotrophic flagellates $<5 \mu \mathrm{m}$ were probably the most significant grazers in this size fraction, based on their abundances and potential clearance rates (Lessard \& Murrell 1996). Over the year, the abundance and biomass of heterotrophic protists $<20 \mu \mathrm{m}$ varied over a very small range $(2.9$ to $4.1 \mu \mathrm{g} \mathrm{Cl}^{-1}$, abundances of 346 to $455 \mathrm{ml}^{-1}$, Caron et al. 1995, Lessard \& Murrell 1996, unpubl. data) and did not correlate with chlorophyll concentration. If the $<20 \mu \mathrm{m}$ protists were the major herbivores, changes in grazer biomass, therefore, could not explain the observed changes in community ingestion and clearance rates. Rather, the observed changes imply a behavioral response by individual grazers in the microzooplankton assemblage.

That natural assemblages of grazers appear to respond to changes in food concentration in a predictable fashion seems remarkable. There is no a priori reason to expect that mixed assemblages of grazers from different seasons, presumably not identical in their species make-up, would respond in a uniform way to changes in prey concentration (and species composition). However, the data presented here suggest that they do, implying a similarity in the functional responses of individual species of herbivores. It is not known whether there is a seasonal succession in species of heterotrophic flagellates in the Sargasso Sea. However, similarity in functional responses of indi- 
vidual species of flagellates may not be unexpected, as the mean cell size of heterotrophic flagellates changes very little with season (41 and $47 \mu^{3}$ in March-April and August, respectively, Caron et al. 1995). If ingestion and clearance rates are primarily a function of size of the grazer, as they appear to be (Fenchel 1987), then the apparent community functional response of natural grazer assemblages in the Sargasso Sea may not be so surprising.

It is significant to note that the threshold value estimated here is similar to the annual minimum in chlorophyll concentration found in the mixed layer in the Sargasso Sea throughout the stratified summer and fall period $10.04 \mathrm{\mu g} \mathrm{l}^{-1}$. August 1989 mixed layer average, Malone et al. $1993 ;<0.05 \mu g \mathrm{l}^{-1}$ in August and October, multiyear data set from BATS, Michaels \& Knap 1996). The similarity in the apparent threshold feeding level and the observed minimum chlorophyll concentrations in the Sargasso Sea is consistent with the idea that grazer behavior may determine the minimum level of phytoplankton biomass. Determining the mechanism(s) that set the minimum level of phytoplankton standing stock in the oceans is important to understanding how ocean ecosystems function. Therefore, further research should be directed at verifying whether the threshold feeding behavior of grazers suggested by our data set is operating in oligotrophic and other oceanic systems.

Acknowledgements. We thank the crews and officers of the RV 'Gyre' and the RV 'Oceanus' We thank Michael Foy and Rick Skinner for their excellent technical assistance, Katrin Bockstahler, Carol Falkenhayn and Sharon Sandgathe for their help at sea and Dora P. Henry for editing. Special gratitude is extended to Bruce Frost, Karl Banse and Peter Jumars for sharing their insights and critical review of drafts of this manuscript. The comments of Robert Sanders and 3 anonymous referees are appreciated. This work was supported by NSF grants OCE-8916165 and OCE-9014418 to E.J.L.

\section{LITERATURE CITED}

Andersen T, Schartau AK, Paasche E (1991) Quantifying extnrnal and internal nitrogen and phosphorus pools, as well as nitrogen and phosphorus supplied through remineralization, in coastal marine plankton by means of a dilution technique. Mar Ecol Prog Ser 69:67-80

Anderson P (1988/89) Functional biology of the choanoflagellate Diaphanoeca grandis Ellis. Mar Microb Food Webs 3:35-50

Banse K (1992) Grazing, temporal changes of phytoplankton concentrations, and the microbial loop in the open sea. In: Falkowski P (ed) Primary productivity and biogeochemical cycles in the sea. Plenum Press, New York, p 1-32

Banse K (1995) Zooplankton: pivotal role in the control of ocean production. ICES J Mar Sci 52:265-277

Banse K, English DC (1994) Seasonality of coastal zone color scanner phytolankton pigment in the offshore oceans. $\mathrm{J}$ Geophys Res 99:7323-7345
Beers JR, Reid FM, Stewart GL (1982) Seasonal abundance of the microzooplankton population in the North Pacific Central Gyre. Deep-Sea Res. 29:227-245

Brand LE, Guillard RR, Murphy LS (1981) A method for rapid and precise determination of acclimated phytoplankton reproduction rates. J Plankton Res 3:193-201

Brzezinski MA (1988) Vertical distribution of ammonium in stratified oligotrophic waters. Limnol Oceanogr 33: $1176-1182$

Burkill P, Edwards E, John A, Sleigh M (1993) Microzooplankton and their herbivorous activity in the northeastern Atlantic Ocean. Deep-Sea Res II 40:479-493

Burkill P, Mantoura R, Llewellyn C, Owens N (1987) Microzooplankton grazing and selectivity of phytoplankton in coastal waters. Mar Biol 93:581-590

Campbell L, Carpenter E (1986a) Diel patterns of cell division in marine Synechococcus spp. (Cyanobacteria): use of the frequency of dividing cells technique to measure growth rate. Mar Ecol Prog Ser 32:139-148

Campbell L, Carpenter E (1986b) Estimating the grazing pressure of heterotrophic nanoplankton on Synechococcus spp. using the seawater dilution and selective inhibitor techniques. Mar Ecol Prog Ser 33:121-129

Caron DA, Dam HG, Kremer P, Lessard EJ, Madlin LP, Malone TC, Napp JM, Peele ER, Youngbluth MJ (1995) The contribution of microorganisms to particulate carbon and nitrogen in surface waters of the Sargasso Sea near Bermuda. Deep-Sea Res I 42:943-972

Chisholm S, Olson R, Zettler E, Goericke R, Waterbury J, Welschmeyer $N$ (1988) A novel free-living prochlorophyte abundant in the oceanic euphotic zone. Nature 334: $340-343$

Choi JW (1994) The dynamic nature of protistan ingestion response to prey abundance. J Euk Microbiol 41:137-146

Eccleston-Parry JD, Leadbeater BS (1994) A comparison of the growth kinetics of six marine heterotrophic nanoflagellates fed with one bacterial species. Mar Ecol Prog Ser 105:167-177

Eppley RW (1980) Estimating phytoplankton growth rates in the oligotrophic oceans. In: Falkowski PG (ed) Primary productivity in the sea. Plenum Press, New York, p 231-242

Evans GT, Paranjape MA (1992) Precision of estimates of phytoplankton growth and microzooplankton grazing when the functional response of grazers may be nonlinear. Mar Ecol Prog Ser 80:285-290

Fasham M, Ducklow H, McKelvie S (1990) A nitrogen-based model of phytoplankton dynamics in the oceanic mixed layer. J Mar Res 48:591-639

Feldman G, Kuring N, Ng C, Esaias W, McClain C, Elrod J, Maynard N, Endres D, Evans R, Brown J, Walsh S, Carle M, Podesto G (1989) Ocean color: availability of the global data set. EOS 70:634-641

Fenchel T (1987) Ecology of Protozoa. Science Tech, Inc, Madison, WI

Fitzwaler SE, Knauer GA, Martin JH (1982) Metal contamınation and its effect on primary production measurements. Limnol Oceanogr 27:544-551

Frost BW (1972) Effects of size and concentration of food particles on the feeding behavior of the marine planktonic copepod Calanus pacificus. Limnol Oceanogr 1.7:805-815

Frost BW (1975) A threshold feeding behavior in Calanus pacificus. Limnol Oceanogr 20:263-266

Frost BW (1980) Grazing. In: Morris I (ed) The physiological ecology of phytoplankton. Studies in ecology 7 . University of California Press, Berkeley, p 465-491

Frost BW, Franzen NC (1992) Grazing and iron limitation in the control of phytoplankton stock and nutrient concentra- 
tion: a chemostat analogue of the Pacific equatorial upwelling zone. Mar Ecol Prog Ser 83:291-303

Gallegos CL (1989) Microzooplankton grazing on phytoplankton in the Rhode River, Maryland: nonlinear feeding kinetics. Mar Ecol Prog Ser 57:23-33

Garside $C$ (1985) The vertical distribution of nitrate in open ocean surface water. Deep-Sea Res 32:723-732

Gifford DJ (1988) Impact of grazing by microzooplankton in the Northwest Arm of Halifax Harbour, Nova Scotia. Mar Ecol Prog Ser 47:249-258

Glover H, Prezelin B, Campbell L, Wyman M, Garside C (1988) A nitrate-dependant Synechococcus bloom in surface Sargasso Sea water. Nature 331:161-163

Goericke R, Welschmeyer N (1993) The marine prochlorophyte Prochlorococcus contributes significantly to phytoplankton biomass and primary production in the Sargasso Sea. Deep-Sea Res I 40:2283-2294

Guillard RR (1975) Culture of phytoplankton for feeding marine invertebrates. In: Smith WL, Chanley MH (eds) Culture of marine invertebrate animals. Plenum Publishing Corp, New York, p 29-60

Heinbokel JF (1978) Studies on the functional role of tintinnids in the Southern California Bight. 1. Grazing and growth rates in laboratory cultures. Mar Biol 47:177-189

Iturriaga R, Marra J (1988) Temporal and spacial variability of chroococcoid cyanobacteria Synchococcus spp. specific growth rates and their contribution to primary production in the Sargasso Sea. Mar Ecol Prog Ser 44:175-181

Iturriaga R, Mitchell BG (1986) Chroococcoid cyanobacteria: a significant component in the food web dynamics of the open ocean. Mar Ecol Prog Ser 28:291-297

Jacobson DM, Anderson DM (1986) Thecate heterotrophic dinoflagellates: feeding behavior and mechanism. J Phycol 22:249-258

Kamiyama T (1994) The impact of grazing by microzooplankton in northern Hiroshima Bay, the Seto Inland Sea, Japan. Mar Biol 119:77-88

Karl DM, Letelier R, Hebel D, Tupas L, Dore J, Christian J, Winn C (1995) Ecosystem changes in the North Pacific subtropical gyre attributed to the 1991-92 El Nino. Nature 373:230-234

Landry MR, Barber RT, Bidigare R, Chai F, Coale KH, Dam $\mathrm{HG}$, Lewis MR, Lindley ST, McCarthy JJ, Roman MR, Stoecker D, Verity PG, White JR (1997) Iron and grazing constraints on primary production in the central equatorial Pacific: an EqPac synthesis. Limnol Oceanogr 42:405-418

Landry MR, Constantinou J, Kirshtein J (1995a) Microzooplankton grazing in the central equatorial Pacific during February and August, 1992. Deep-Sea Res 4:2:657-671

Landry MR, Hassett RP (1982) Estimating the grazing impact of marine micro-zooplankton. Mar Biol 67:283-288

Landry MR, Kirshtein J, Constantinou J (1995b) A refined dilution technique for measuring the community grazing impact of microzooplankton, with experimental tests in the central equatorial Pacific. Mar Ecol Prog Ser 120:53-63

Landry MR, Monger B, Selph K (1993) Time-dependency of microzooplankton grazing and phytoplankton growth in the subarctic Pacific. Prog Oceanogr 32:205-222

Laws EA, DiTullio GR, Redalge DG (1987) High phytoplankton growth and production rates in the North Pacific subtropical gyre. Limnol Oceanogr 34:905-918

Lessard EJ, Murrell MC (1996) Abundance, biomass, and distribution of heterotrophic dinoflagellates and ciliates in the subtropical Sargasso Sea. Deep-Sea Res 1 43:1045-1065

Li WK (1990) Particles in 'particle-free' seawater: growth of ultraphytoplankton and implications for dilution experiments. Can J Fish Aquat Sci 47:1258-1268
Li WK, Dickie PM, Irwin BD, Wood AM (1992) Biomass of bacteria, cyanobacteria, prochlorophytes and photosynthetic eukaryotes in the Sargasso Sea. Deep-Sea Res 39(3/4): $501-519$

Li WK, Subba Rao DV, Harrison WG, Smith JC, Cullen JJ, Irwin B, Platt T (1983) Autotrophic picoplankton in the tropical ocean. Science 219:292-297

Lipschultz F, Zafiriou OC, Ball LA (1996) Seasonal fluctuations of nitrate concentrations in the deep oligotrophic ocean. Deep-Sea Res ll 43:403-419

Lohrenz SE, Knauer GA, Asper VL, Tuel M, Michaels AF Knap AH (1992) Seasonal variability in primary production and particle flux in the northwestern Sargasso Sea U.S. JGOFS Bermuda Atlantic Time-series Study. DeepSea Res I 39:1373-1391

Malone TC, Pike SE, Conley DJ (1993) Transient variations in phytoplankton productivity at the JGOFS Bermuda time series station. Deep-Sea Res I 40:903-924

Menzel DW, Ryther JH (1960) The annual cycle of primary production in the Sargasso Sea off Bermuda. Deep-Sea Res 6:351-367

Menzel DW, Ryther JH (1961) Nutrients limiting production of phytoplankton in the Sargasso Sea, with special reference to iron. Deep-Sea Res 7:276-281

Michaels AF, Knap AH (1996) Overview of the U.S. JGOFS Bermuda Atlantic Time-series Study and the Hydrostation S program. Deep-Sea Res II 43:157-198

Michaels AF, Knap AH, Dow RL, Gundersen K, Johnson RJ, Sorensen J, Close A, Knauer GA, Lohrenz SE, Asper VA Tuel M, Bidigare R (1994) Seasonal patterns of ocean biogeochemistry at the U.S. JGOFS Bermuda Atlantic Timeseries Study site. Deep-Sea Res I 41(7):1013-1038

Neuer S, Cowles T (1994) Protist herbivory in the Oregon upwelling system. Mar Ecol Prog Ser 113:147-162

Olsen RJ, Chisholm SW, Zettler ER, Altabet MA, Dusenberry JA (1990) Spacial and temporal distributions of prochlorophyte picoplankton in the North A.tantic Ocean. DeepSea Res 37:1033-1051

Paffenhöfer GA (1988) Feeding rates and behavior of zooplankton. Bull Mar Sci 43:430-445

Parsons TR, Maita Y, Lalli CM (1984) A manual of chemical and biological methods for seawater analysis. Pergamon Press, New York

Platt T, Subba Rao DV, Irwin B (1983) Photosynthesis of the picoplankton in the oligotrophic ocean. Nature 301 $702-704$

Rivier A, Brownlee DC, Sheldon RW, Rassoulzadegan F (1985) Growth of microzooplankton: a comparative study of bactivorous zooflagellates and ciljates. Mar Microb Food Webs $1: 51-60$

Roman MR, Caron DA, Kremer P, Lessard EJ, Madlin LP, Malone TC, Napp JM, Peele ER, Youngbluth MJ (1995) Spatial and temporal changes in the partitioning of organic carbon in the plankton community of the Sargasso Sea off Bermuda. Deep-Sea Res I 42:973-992

Ryther JH (1969) Photosynthesis and fish production in the sea. Science 166:72-76

Sarmiento JL, Slater RD, Fasham MJ, Ducklow HW, Toggweiler JR, Evans GT (1993) A seasonal three-dimensional ecosystem model of nitrogen cycling in the North Atlantic euphotic zone. Global Biogeochem Cycles 7:417-450

Schöne H, Schöne A (1982) MET 44: a weakly enriched seawater medium for ecological studies on marine plankton algae, and some examples of its application. Bot Mar 25: $117-122$

Sherr BF, Sherr EB, Berman T (1983) Grazing, growth, and ammonium excretion rates of a heterotrophic microflagel- 
late fed with four species of bacteria. Appl Environ Microbiol 45:1196-1201

Sorokin YI, Kopylov AI, Mamaeva NV (1985) Abundance and dynamics of microplankton in the central tropical Indian Ocean. Mar Ecol Prog Ser 24:27-41

Steele JH (1974) The structure of marine ecosystems. Harvard University Press, Cambridge

Steele $\mathrm{JH}_{i}$, Henderson EW (1992) The role of predation in plankton models. J Plankton Res 14:157-172

Stoecker DK (1988) Are marine planktonic ciliates suspension-feeders? J Protozool 35:252-255

Strom SL, Buskey EJ (1993) Feeding, growth, and behavior of the thecate heterotrophic dinoflagellate Oblea rotunda. Limnol Oceanogr 38:965-977

Strom SL, Welschmeyer NA (1991) Pigment-specific rates of phytoplankton growth and microzooplankton grazing in

Editorial responsibility: Robert Sanders,

Philadelphia, Pennsylvania, USA the open subarctic Pacific Ocean. Limnol Oceanogr 36: $50-63$

Taguchi S, DiTullio G, Laws E (1988) Physiological characteristics and the production of mixed layer and chlorophyll maximum phytoplankton populations in the Caribbean Sea and the western Atlantic Ocean. Deep-Sea Res 35: $1363-1377$

Verity PG, Stoecker DK, Sieracki ME, Nelson JR (1996) Microzooplankton grazing of primary production at $140^{\circ} \mathrm{W}$ in the Equatorial Pacific. Deep-Sea Res II 43: $1227-1255$

Waterbury JB, Watson SW, Valois FW, Franks DG (1986) Biological and ecological characterization of the marine unicellular cyanobacterium Synechococcus. In: Platt T, Li WK (eds) Photosynthetic picoplankton. Can Bull Fish Aquat Sci 214:71-120

Submitted: August 22, 1997; Accepted: June 15, 1998 Proofs received from author(s): October 14, 1998 